\title{
KNOWING TO EMPOWER: STUDY OF THE DIFFICULTIES OF THE INFORMAL CAREGIVER
}

\author{
Rosa Martins ${ }^{1}$, Francisco Almeida ${ }^{2}$, Susana Batista ${ }^{1}$, \& Nélia Carvalho ${ }^{1}$ \\ ${ }^{I}$ Higter School of Health, Polytechnic Institute of Viseu (Portugal) \\ ${ }^{2}$ Continuing Care Unit- ACREDITA (Portugal)
}

\begin{abstract}
The Informal Caregiver (IC) faces multiple difficulties in caring for the dependent person. Thus, the purpose of this study is to identify the levels and dimensions of the difficulties experienced by ICs in caring for the dependent person. Methods: Observational, cross-sectional, and descriptive quantitative study, using a non-probability convenience sample composed of 119 ICs from the Central region Portugal. The measuring instrument used included a sociodemographic data form and an Informal Caregiver Difficulties Assessment Scale (EADCI). Results: Moderate difficulties were mostly observed, which were higher in the dimensions caring for myself and activities of daily living. On the other hand, health status/ risk prevention and community and social resources, were assessed in a more positive way. Conclusion: These results indicate that ICs have difficulties at various levels of caring for the dependent person, strengthening the need to implement new strategies capable of responding to these challenges.
\end{abstract}

Keywords: Informal caregiver, difficulty, care, dependent person.

\section{Introduction}

The caregiver is defined by the International Classification for Nursing Practice (ICNP) as individual: assists with identification, prevention, or treatment of illness or disability, attends to the needs of a dependent (ICN, 2016). It is a key element in the rehabilitation process of the dependent person, since it will ensure the satisfaction of the patient's basic Activities of Daily Living (ADL's), after returning home.

The informal caregiver (IC) usually has different responsibilities, providing unpaid assistance to a dependent person. They perform tasks of daily living simultaneously with other activities related to health care, namely: taking medication, treating wounds, monitoring equipment, and others. These are usually family members or close relatives who provide partial or total care to the dependent person with self-care difficulties, facilitating his/her well-being and helping him/her in different tasks and ADLs. The current demographic changes, with an increasing weight of the elderly population, have translated into an increase in longevity, although not always in good health and without disability, which conditions the future guarantee to the accessibility, quality and sustainability of health care and the role of caregivers (Araújo \& Martins, 2016). The challenges posed by an aging population require efforts to assess the value of these invisible and growing care responsibilities, which puts increased pressure on caregivers across Europe (CÈS S, et al., 2019).

A study developed by Andrade, et al. (2019) showed an effective lack of training and support to the caregivers of dependent people, who experienced serious difficulties in providing continuity of care at home. It should be noted that $97.4 \%$ of the surveyed caregivers reported not having received guidance or training on care provision from the health team. Caring for dependent people is often associated with situations of overload that translate into physical, psychological, emotional, and even financial problems (Oldenkamp, et al., 2018). These constraints cause ICs to present a set of difficulties and "unpreparedness" that hinder their performance, leading them in many circumstances even to exhaustion. Therefore, and taking into account the difficulties reported by ICs, it is essential to identify the priority areas of intervention, in order to empower them to develop the provision of health care, while considering the levels of overload. The dimensions of care, often reported by ICs, are mainly associated with self-care, feeding, hygiene and comfort, dressing / undressing, mobilisations, transfers, use of sanitary equipment, and therapeutic management. Dixe et al. (2019), (Petronilho, 2016). However, it should be noted that the situation of the IC of a dependent person is unique and incomparable, and the caregiver's circumstances, family dynamics, and cultural aspects should be considered. In addition, there are cultural 
rules that impose the responsibility of caring, and, for this reason, informal caregivers experience difficulties differently. In this sense, it becomes essential to have access to an educational pedagogy, with support interventions according to their needs, empowering them to respond to new challenges, but for this, it is essential to know their real difficulties (Oldenkamp et al., 2018).

Thus, this research aimed to identify levels and dimensions of the difficulties experienced by informal caregivers in caring for the dependent person.

\section{Methods}

Observational, cross-sectional and descriptive study, with a quantitative nature. The sample used is a non-probability convenience sample composed of 119 ICs, from the central region of Portugal. Participant eligibility emerged from the following inclusion criteria: being the main informal caregiver of a dependent person for at least 6 months, being aged $\geq 18$ years and the dependent person having a dependence level with a Barthel Index Score $<90$. A questionnaire was used as a data collection instrument (DCI), composed of three sections: a first section with sociodemographic data, a second one with psychosocial context data, and a third one composed of a Scale of Assessment of the Informal Caregiver's Difficulties (AICD) built, validated and adapted to the Portuguese population by Martins \& Almeida, 2018. This Lickert-type scale is composed of 30 items, with four response options (1 minor difficulties, ... and 4 major difficulties) and grouped into four dimensions: activities of daily living (ADLs); health status / risk prevention; community and social resources; and caring for myself. Data were collected after permission was granted by the Executive Board of the ACeS Dão-Lafões. The procedures were performed in accordance with the ethical principles of the Declaration of Helsinki and were also authorized by the Ethics Committee of the University where the study was conducted, through Opinion No.22/2018. The statistical treatment was performed using the Statistical Package Social Science version 22.0 for Windows and was processed using descriptive statistics.

\section{Results}

The study sample included 119 informal caregivers, mostly females (83.2\%), aged between 19 and 87 years, with a mean of 60.14 years $( \pm 13.71)$ (see Table 1$)$.

Table 1. Distribution of the sample according to age and gender.

\begin{tabular}{c|ccccccccc}
\hline Gender & $\mathbf{n}$ & $\mathbf{\%}$ & Min. & Max. & $\bar{x}$ & DP & CV\% & $\frac{S k}{\text { Std. Error }}$ & $\frac{\boldsymbol{K}}{\text { Std. Error }}$ \\
\hline Female & 99 & 83,2 & 36 & 87 & 58,51 & 11,997 & 20,50 & 1,695 & $-0,782$ \\
Male & 20 & 16,8 & 19 & 84 & 68,25 & 18,496 & 27,10 & $-2,922$ & 1,731 \\
\hline Total & 119 & 100 & 19 & 87 & 60,14 & 13,711 & 22,80 & 0,081 & $-0,755$ \\
\hline
\end{tabular}

Caregivers are mostly $(78.2 \%)$ married or living in a consensual union and have completed secondary education $(52.9 \%)$ as an academic qualification. In professional terms, $32.8 \%$ of the ICs are still working (only 35.3\% are retired), working full-time, during daytime working hours (34.7\%), as employees and with a monthly income ranging between 500 and 1000EUR. The majority (65.9\%) of the ICs are wives and daughters of the dependent person, have been providing care for over 2 years $(61.3 \%)$ and approximately half $(50.4 \%)$ of the sample devotes 12 hours daily to care. The motivations behind caring are: caring for pleasure or own will (52.1\%), having no other alternative (34.5\%), and moral/religious obligation $(25.2 \%)$.

Table 2 expresses the difficulties expressed by the ICs: consequently, we found that the greatest difficulties are associated with the dimension caring for myself $(=56.08 \%, \pm 27.383)$, and the Activities of daily living $(=51.79 \%, \pm 27.215)$. Contrarily, the least difficulties are linked to Community and social resources $(=35.57 \%, \pm 25.918)$ and Health status and risk prevention $(=39.47 \%, \pm 26.117)$. The analysis of the participants' difficulties in global terms (global scale score) reveals significant levels of difficulties $(=46.04 \%, \pm 22.430)$, as we can see in Table 2 . 
Table 2. Difficulties of ICs per dimension and overall value of EADCI.

\begin{tabular}{|c|c|c|c|c|c|c|c|c|c|}
\hline Dimensions & $\mathbf{n}$ & $\%$ & $\underset{\%}{\operatorname{Min} .}$ & $\begin{array}{c}\text { Max. } \\
\%\end{array}$ & $\begin{array}{l}\bar{x} \\
\%\end{array}$ & $\begin{array}{l}\text { DP } \\
\%\end{array}$ & $\mathrm{CV} \%$ & $\frac{S k}{\text { Std. Error }}$ & $\frac{K}{\text { Std. Error }}$ \\
\hline $\begin{array}{l}\text { Activities of daily } \\
\text { living }\end{array}$ & 119 & 100 & 0,0 & 100,0 & 51,79 & 27,215 & 52,55 & $-0,500$ & $-1,959$ \\
\hline $\begin{array}{l}\text { Health status and } \\
\text { risk prevention }\end{array}$ & 119 & 100 & 0,0 & 100,0 & 39,47 & 26,117 & 65,64 & 2,108 & $-1,375$ \\
\hline Caring for myself & 119 & 100 & 0,0 & 100,0 & 56,08 & 27,383 & 48,828 & $-0,248$ & $-1,764$ \\
\hline $\begin{array}{l}\text { Community and } \\
\text { social resources }\end{array}$ & 119 & 100 & 0,0 & 100,0 & 35,57 & 25,918 & 72,865 & 2,189 & $-0,473$ \\
\hline Global Factor & 119 & 100 & 3,45 & 100,0 & 46,04 & 22,430 & 48,719 & 1,495 & $-1,198$ \\
\hline
\end{tabular}

In order to quantify the levels of difficulties by groups, we observed that $46.2 \%$ of the sample had moderate difficulties, $28.6 \%$ had low difficulties and $25.2 \%$ had high difficulties. The analysis by gender shows that men are positioned essentially (70\%) at moderate levels, while women are distributed across the different levels (see Table 3), with the statistical differences by gender being significant $(\mathrm{X} 2=7.617 ; \mathrm{p}=0.022)$ and confirmed by the adjusted residual values.

Table 3. Distribution of the sample by levels of difficulty, according to gender.

\begin{tabular}{r|cccccccc}
\hline \multirow{2}{*}{$\begin{array}{l}\text { GCs } \\
\text { ICnder }\end{array}$} & \multicolumn{2}{c}{ Female } & \multicolumn{2}{c}{ Male } & \multicolumn{2}{c}{ Total } & Adjusted Residuals \\
\cline { 2 - 10 } Difficulties & $\mathbf{n}$ & $\mathbf{\%}$ & $\mathbf{n}$ & $\mathbf{\%}$ & $\mathbf{n}$ & $\mathbf{\%}$ & Female & Male \\
\hline Reduced difficulties & 33 & $\mathbf{3 3 , 3}$ & 1 & 5,0 & 34 & 28,6 & $\mathbf{2 , 6}$ & $-2,6$ \\
Moderate difficulties & 41 & 41,4 & 14 & $\mathbf{7 0 , 0}$ & 55 & 46,2 & $-2,3$ & $\mathbf{2 , 3}$ \\
$\quad$ High difficulties & 25 & 25,3 & 5 & 25,0 & 30 & 25,2 & 0,0 & 0,0 \\
\hline Total & 99 & 100,0 & 20 & 100,0 & 119 & 100,0 & & \\
\hline
\end{tabular}

\section{Discussion of results}

The participant's sociodemographic characteristics are in line with other studies recently conducted in the Portuguese context and targeting similar populations (Martins et al., 2018; Andrade et al., 2019). This is a sample mostly composed of female informal caregivers, with a mean age of 60.14 years, with married marital status and with the second cycle of education as academic qualification, confirming the expected correlation with the statistical data published in Portugal by the National Statistics Institute (INE, 2019). The monthly income earned by the majority is around low values (500-1000). These data are in line with those of Matos, (2019); Martins \& Santos (2020) when they refer that there are groups of informal caregivers (mostly elderly) who are at the poverty line with very strong impacts on their quality of life. The sociodemographic profile of these ICs is characterized by being mostly women, relatives of the dependent person (wives and daughters), distributed by different professional situations (active, retired and unemployed), dedicating about 12 hours daily to care. Despite the change in gender attitudes and the rapid entry of women into the labour force in recent decades, women continue to play an important role in managing the home and caring for family members, even in situations in which they need to cumulatively exercise their professional activity, which has obvious implications in other areas, such as the reduction of leisure and social activities, leading to higher levels of overload, anxiety and stress (Costa \& Castro, 2016). However, characteristics, such as level of education, employment and socioeconomic status, present variations in different societies and countries. (Martins \& Santos (2020). A study conducted by Sequeira (2018) showed that the main reasons for assuming the role of caregiver are: own initiative, family decision, being the only person who could care, and request from the dependent person. Matos, (2019) also mentions that there are many reasons that lead ICs to assume this role, such as the obligation to care due to social norms, affective bounds, commitment, piety, or altruism. These data are in line with those of this study, since they conveyed: caring for pleasure or own will, having no other alternative and also the moral / religious obligation of retribution. 
Studies converge in highlighting the variability of feelings and difficulties expressed by ICs. It is known that the caregiver is unique, incomparable, involved in a family dynamic and is conditioned by cultural aspects (Hajek \& König 2016). Therefore, moderate difficulties were observed (for almost half of the sample) low difficulties and high difficulties for smaller groups. There is a clear difference between men and women as the former position themselves essentially at moderate levels, while women are distributed over different levels. However, the inequality of the sample has to be taken into account, as most of the participants are female and care for their relatives for longer periods and longer daily time. On the other hand, caring is constantly changing and should be considered as a permanent state of personal development, transformations and ontological self-understanding that leads to more positive perceptions (Oliveira \& Carraro, 2016).

It was also shown that the major difficulties are associated with the dimension caring for myself and the activities of daily living. These are data corroborate those of Dixe (2018), when he advocates that the daily routine of the ICs with extensive hours of care in assisting and supervising the ADLs of the dependent person is neglected in their self-care, leisure and/or social activities that remain in the background, making them vulnerable to the development of depression, stress and lower quality of life. Added to these difficulties, is the need to actively assist and supervise basic activities of daily living for long periods of the day and for which they feel they are not prepared (Martins, et al., 2018). In the opposite direction, the difficulties are smaller when the dimensions community and social resources and health status and risk prevention are associated. In fact, in recent years there has been a special attention to ICs, through greater awareness of the implementation of training programs and facilitating access to social resources (Petronilho, 2016). On the other hand, psychosocial predictors of the caregiver identified so far, include greater socio-emotional support, lower subjective burden, higher quality relationship with the dependent person and higher intrinsic motivation for caregiving (Greenwood \& Smith, 2019).

\section{Conclusions}

Informal care is a complex and dynamic process, which is constantly changing and should be analysed not only from the perspective of a standardized care model, but also based on the actions and difficulties experienced and felt by the caregiver.

The ICs present real difficulties of moderate level, with greater demands in assisting and supervising the activities of daily living and self-care. The dimensions related to community and social resources and also the health status and risk prevention are assessed in a more positive way, which may be associated with the development of communication and organizational skills, among other anticipatory care for caregivers' empowerment.

Therefore, it is important to understand in future studies, which are the predictors of the difficulties and lived experiences, but also of the positive motivations facilitating caregiving, since there are internal and external factors that may influence the well-being of the informal caregiver.

\section{References}

ACSS (2019). Administração Central do Sistema de Saúde, IP. Rede Nacional de Cuidados Continuados Integrados - onde estamos. Retrieved from https://www.arcgis.com/apps/ PublicInformation/index.html?appid=7874a58d37a248a481d567d85be88134

Andrade, L. M., Costa, M. D. F. M., Caetano, J. Á., Soares, E., \& Beserra, E. P. (2019). A problemática do cuidador familiar do portador de acidente vascular cerebral. Revista da Escola de Enfermagem da USP, 43(1), 37-43. http://dx.doi.org/10.1590/S0080-62342009000100005

Araújo, F. \& Martins, T. (2016). Avaliação dos cuidadores: considerações e orientações para a prática. In T. Martins, et al. (Org.), A pessoa dependente \& o familiar cuidador (pp. 113-130). Porto: Escola Superior de Enfermagem do Porto.

Bruggen, S. V., Gussekloo, J., Bode, C., Touwen, D. P., Engberts, D. P., \& Blom, J. W. (2016). Problems experienced by informal caregivers with older care recipients with and without cognitive impairment. Home Health Care Services Quarterly; Vol. 35: 1, 11-24. Retrieved from http://dx.doi.org/10.1080/01621424.2016.1145166

Costa, S. R. D. da, \& Castro, E. A. B. de (2016). Autocuidado do cuidador familiar de adultos ou idosos dependentes após a alta hospitalar. Rev Bras Enferm.; 67(6), 979-986. Retrieved from http://www.scielo.br/pdf/reben/v67n6/0034-7167-reben-67-06-0979.pdf

DGS (2015). Direção-Geral da Saúde. Plano nacional de saúde: revisão e extensão a 2020. Lisboa: Direção-Geral da Saúde. Retrieved from http://1nj5ms21li5hdggbe3mm7ms5.wpengine.netdnacdn.com/files/2015/06/Plano-Nacional-de-Saude-Revisao-e-Extensao-a-2020.pdf.pdf 
Dixe, M. A. C. R., Teixeira, L. F. C., Areosa, T. J. T. C. C., Frontin, R. C., Peralta, T. J. A., \& Querido, A. I. F. (2019). Needs and skills of informal caregivers to care for a dependent person: a crosssectional study. BMC Geriatrics; 19, 255, 2-9. Retrieved from https://doi.org/10.1186/s12877-019-1274-0

Greenwood, N., Smith R. (2019). Motivations for being informal carers of people living with dementia: A systematic review of qualitative literature. BMC geriatrics; 19(1): 169.)

Hajek, A., \& König, H. H. (2016). Informal caregiving and subjective well-being: evidence of a population-based longitudinal study of older adults in Germany. J Am Med Dir Assoc.; 17, 300-055. Retrieved from https://www.ncbi.nlm.nih.gov/pubmed/26705001

ICN (2016). International Council of Nurses. CIPE® Versão 2015 - Classificação Internacional para a Prática de Enfermagem. Genebra: ICN.

INE (2019). Instituto Nacional de Estatística. Estimativas de população residente em Portugal 2018. Lisboa: INE. Retrieved from https://www.ine.pt/xportal/xmain?xpid=INE\&xpgid=ine_destaques\&DESTAQUESdest_boui=354 227526\&DESTAQUESmodo $=2$

Martins, R., Rodrigues, A., Andrade, A., Albuquerque, C., \& Martins, C. (2018) Perception of informal caregivers on planning for the discharge of hospitalised elderly patients. Rev Enf Rol, vol. 41 $n^{\circ} 11-12$ (nov-dec) pp 193-197. http://hdl.handle.net/10400.19/5330

Martins, R., \& Santos, C. (2020). Capacitação do cuidador informal: o papel dos enfermeiros no processo de gestão da doença. Gestão E Desenvolvimento, (28), 117-137. https://doi.org/10.34632/gestaoedesenvolvimento.2020.9468

Matos, N. A. M. de (2019). Dificuldades do cuidador informal no cuidar da pessoa dependente. (Dissertação de Mestrado). Instituto Politécnico de Viseu. Escola Superior de Saúde de Viseu. Retrieved from http://repositorio.ipv.pt/handle/10400.19/5478

Oldenkamp, M., Bültmann, U., Wittek, R. P. M., Stolk, R. P., Hagedoorn, M., \& Smidt, N. (2018). Combining informal care and paid work: The use of work arrangements by working adult-child caregivers in the Netherlands. Health Soc Care Community; 26(1), e122-e131. doi: $10.1111 /$ hsc. 12485 .

Oliveira M.D., Carraro T.E. Cuidado em Heidegger: uma possibilidade ontológica para a enfermagem. Revista Brasileira de Enfermagem, 2016; 64(2): 376-380

Petronilho, F. (2016). Preparação do regresso a casa. In T. Martins, et al. (Org.), A pessoa dependente \& o familiar cuidador (pp. 73-93). Porto: Escola Superior de Enfermagem do Porto.

Sequeira, C. (2018). Cuidar de idosos com dependência física e mental. (2a ed.). Lisboa: Lidel - Edições Técnicas. 